\title{
アルシンー加熱石英セル原子吸光法による大気粉じん中の ヒ素の高感度定量
}

\author{
山重 隆*®, 山本学, 山本 勇麓** \\ (1980 年 11 月 13 日受理)
}

テトラヒドロホウ酸ナトリウム $(\mathrm{STHB})$ を用いてヒ素をアルシンに還元し，これを $1000{ }^{\circ} \mathrm{C} に$ 加 熱された石英セル中に導いて原子化させる原子吸光法を大気粉じん中のヒ素定量に適用した. 大気粉じ え中のヒ素は硝酸と過酸化水素水で加熱することによって定量的に抽出できること, STHB は錠片, 溶 液のいずれでも使用できること，種々遷移金属イオンがヒ素の数万倍含まれる系でもヨウ化カリウム を加えることによってこれらの妨害をマスキングできることなどが分かった．1\%吸収による感度は $193.7 \mathrm{~nm}$ のヒ素共鳴線で $1.5 \mathrm{ng}, 197.3 \mathrm{~nm}$ で $2.7 \mathrm{ng}$ であった. $0.1 \mu \mathrm{g}$ の標準溶液による 10 回の 繰り返し測定による相対標準偏差は $2 \%$ 以下であった.

\section{1 緒 言}

ヒ素は自然界にも広く分布しているが，エネルギー源 として多量に使用されている化石然料中には重油で $(0.2$ 〜0.7) ppm, 石炭で $(0.25 \sim 2) \mathrm{ppm}$ 含まれていると言わ れている1). 大気粉じん中のヒ素の高感度かつ簡便な分 析法を確立することは, 環境科学の面からも重要であ る.

微量ヒ素の測定法としては, 塩化スズ(II) とヨウ化カ リウムを含む塩酸溶液に亜鉛末錠剤を加え, 発生したア ルシンを水素炎中に導入する原子吸光法が一般的である が2) 4), 最近, 七素含量の少ない STHB を還元剤とする

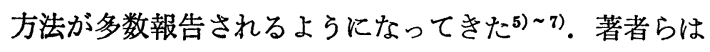
STHB を用いる場合の遷移金属イオンによる負の干渉 がョウ化カリウムを添加することで大幅に抑制できるこ とを先に報告した ${ }^{89)}$. 今回は STHB を溶液として用い る方法についても検討し, 加熱石英セル原子化法と組み 合わせて大気粉じん中のヒ素の高感度分析法を確立した ので, これらについて報告する.

\section{2 実験}

\section{$2 \cdot 1$ 装置及び試薬}

原子吸光光度計：日本ジャーレル・アッシュ社製の

* 広島県環境センター：広島県広島市南区皆実町 1-6 $-29$

**広島大学理学部分析化学教室 : 広島県広島市中区東 千田町 1-1-89
AA-8200 型原子吸光光度計に浜松テレビ社製のヒ素及 び重水素中空陰極ランプをセットした.

アルシン発生捕集・原子化装置 : 既報10)11) と同一の装 置を用いた。なお，反応びえは STHB 溶液が注入でき るように側管付きに改良した。. 又，アルシンの発生捕集 系内の減圧ができるように減圧コックをバッフォタンク と圧力ゲージの間に取り付けた.

ヒ素標準溶液 $(1000 \mu \mathrm{g} / \mathrm{ml})$ ：和光純薬製の特級ヒ酸 カリウム $1.201 \mathrm{~g}$ を水に溶かし $500 \mathrm{ml}$ とした. 使用に 当たっては，この溶液を水で希釈して用いた.

STHB 溶液 $(3 \%, \mathrm{w} / \mathrm{v})$ : 関東化学社製の STHB $3 \mathrm{~g}$ を $0.05 \%$ の水酸化ナトリウム溶液 $100 \mathrm{ml}$ に溶 かし，ニトロセルロースろ紙 (Sartorius-Membran filter SM-11306)12) あるいはセルロースろ紙（東洋ろ紙 No. 5A）でろ過して調製した。いずれの場合も 1 週間は使 用できた.

STHB 錠片：関東化学社製の STHB と和光純薬製の 酸処理カオリン末を用いて交献9）に従い調製した.

ヨウ化カリウム溶液 $(40 \%, w / v)$ ：和光純薬製の特 級ヨウ化カリウム $40 \mathrm{~g}$ を水に溶かし $100 \mathrm{ml}$ とした.

L-アスコルビン酸溶液 $(20 \%, \mathrm{w} / \mathrm{v})$ ：和光純薬製の 特級 L-アスコルビン酸 $20 \mathrm{~g}$ を水に溶かし $100 \mathrm{ml}$ とし た.

その他の試薬, 窒素 : すべて既報10)11)と同様である.

\section{2 標準操作}

2.2.1 前処理 粉じん試料の一定量をコニカルビー カーに採り, 硝酸 $20 \mathrm{ml}$ と $30 \%$ 過酸化水素水 $3 \mathrm{ml}$ を 加えて時計ざらで覆い，ホットプレート上で約 1 時間加 熱し， $30 \%$ 過酸化水素水 $2 \mathrm{ml}$ を追加して更に 1 時間 加熱する. 室温まで放冷後, セルロースろ紙（東洋ろ紙 
No. 5A) を用いて不溶解分を除去し，ろ液を蒸発乾固す る. 蒸発残さを $0.5 \mathrm{M}$ の塩酸で溶かし, セルロースろ 紙(東洋ろ紙 No. 5B) を通して $50 \mathrm{ml}$ のメスフラスコ に採り定容とする.

2.2.2 定量 試料溶液の一定量 \{七素を $(0.01$ 0.3) $\mu \mathrm{g}$ 含む\} を反応びんに採り, 塩酸 $4 \mathrm{ml}, 40 \%$ ヨウ

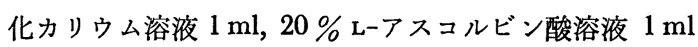
を加えて水で全量を約 $25 \mathrm{ml}$ とし，アルシンの発生捕集 装置にセットする. マグネチックスターラーで内部をか くはんしながら流路コックを sweep にして反応系内を 窒素置換する・1 分後に流路コックを by pass 側に切り 替光, 減圧コックを開いて系内を大気圧とした後, 再び 閉める. 次に $3 \% \mathrm{STHB}$ 溶液 $2.5 \mathrm{ml}$ を反応びん中に注 射器で注入する・ただし，STHB 錠剤を使用する場合 は，錠剤 1 個をオブラートに包み反応びんにすばやく投 入し直ちに閉める. 30 秒後に流路コックを sweep に して発生ガスを原子吸光光度計の原子化部へ導入し吸光 度を測定する.なお, ランプ電流はヒ素が $10 \mathrm{~mA}$, 重水 素が $25 \mathrm{~mA}$, スペクトル幅は $0.32 \mathrm{~nm}$, 共鳴線は 197.3 $\mathrm{nm}$ ，キャリヤーガス (窒素) は $21 / \mathrm{min}\left(0.5 \mathrm{~kg} / \mathrm{cm}^{2}\right)$, 加熱石英セル温度は $1000{ }^{\circ} \mathbf{G}$ である.

\section{3 結果と考察}

\section{1 測定条件の検討}

3.1.1 塩酸濃度と STHB 量 $3 \% \mathrm{STHB}$ 溶液を使 用する場合の条件について検討した. $2 \cdot 2 \cdot 2$ の操作にお ける塩酸濃度と吸光度の関係を Fig. 1 に, 又 $3 \%$ STHB 溶液の注入量と吸光度の関係を Fig. 2 に示した. これ

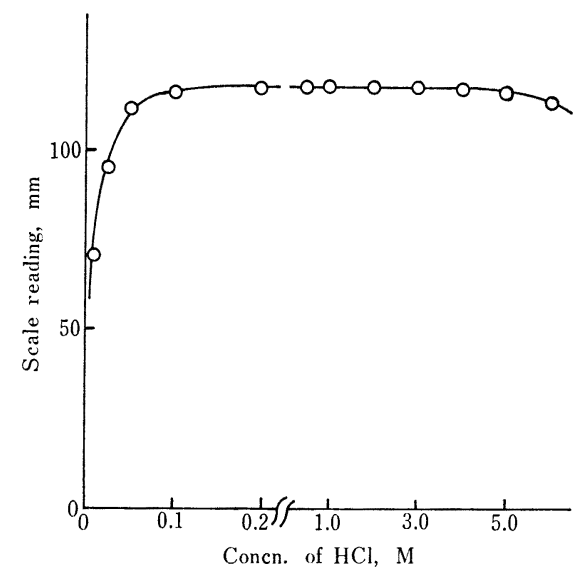

Fig. 1 Effect of the concentration of $\mathrm{HCl}$ on absorbance of As As : $0.30 \mu \mathrm{g} ; \mathrm{STHB}$ solution $-197.3 \mathrm{~nm}$

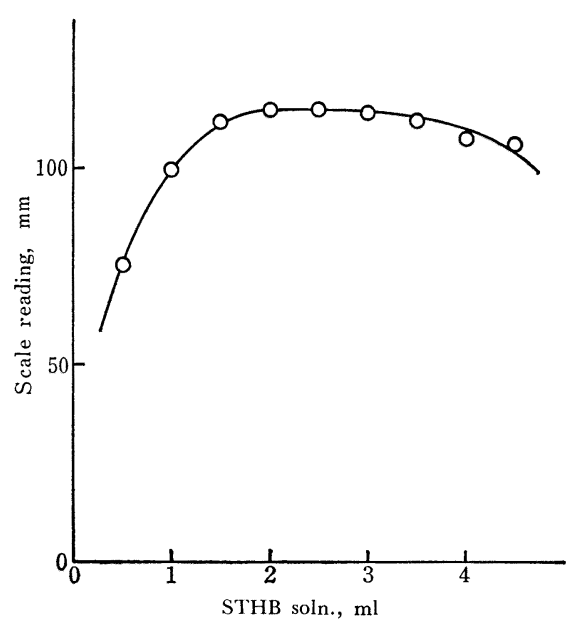

Fig. 2 Effect of the added amounts of $3 \%$ STHB solution on absorbance of As As : $0.30 \mu \mathrm{g}, 197.3 \mathrm{~nm}$

らの結果から, $3 \% \mathrm{STHB}$ 溶液を用いる場合は $2 \mathrm{M}$ の 塩酸系に $2.5 \mathrm{ml}$ の STHB 溶液を加えることとした. 一方, STHB 錠剂を用いる場合は文献9) に従い, $2 \mathrm{M}$ の 塩酸系に錠凧 1 個を加えた.なお, 錠剤 1 個からの水素 発生量は $3 \%$ 溶液の $2.5 \mathrm{ml}$ に対応しており, アルシン の発生条件に対する STHB の必要量は溶液の場合と錠 剤の場合で差は認められなかった。

3.1.2 STHB 溶液の注入速度之捕集時間 STHB 溶液の注入速度及び 発生ガスの捕集時間 (STHB の添 加から発生アルシンをセルへ導入するまでの時間）が吸 光度に与える 影響を調べた. 注入速度は $(2 \sim 20)$ 秒の 範囲では吸光度にはほとんど影響を与えなかった．捕集 時間は 10 秒以下では吸光度の低下や変動が認められた が，(15〜120) 秒ではこのような現象はなく，一定の高 い吸光度が得られた. 従って, STHB 溶液は 4 秒程度で 注入乙捕集時間は 30 秒と決めた.

3.1.3 加熱石英セル温度 セル温度と吸光度の関係 は, セレン10), アンチモン ${ }^{11)}$ の場合に見られたのと同様 に $700^{\circ} \mathrm{C}$ から $900^{\circ} \mathrm{G}$ の範囲では急速に吸光度が増加 し，950 $\mathrm{C}$ 以上で一定值に近づく現象が認められた. 従 って, 測定は $1000^{\circ} \mathrm{G}$ で行った.

3.1.4 キャリヤーガス流量 窒素流量と吸光度の関 係を調べた. 吸光度は窒素流量の増加とともに増大する が，セレン ${ }^{10)}$ ，アンチモン11)の場合と異なり $21 / \mathrm{min}$ 以 上ではかなり急速に低下し, $51 / \mathrm{min} て ゙ は ~ 21 / \mathrm{min}$ のと きの約 $1 / 2$ となった・標準操作は $21 / \mathrm{min}\left(0.5 \mathrm{~kg} / \mathrm{cm}^{2}\right)$ とした. 
3.1.5 検量線と精度 STHB を溶液として加えた 場合と錠剤として加えた場合のそれぞれ $193.7 \mathrm{~nm}$, $197.3 \mathrm{~nm}$ に抹ける検量線を Fig. 3 に示した. $1 \%$ 吸収 による感度は, 錠剤 $-193.7 \mathrm{~nm}$ が $1.2 \mathrm{ng}$ で最も高く, 次いで溶液 $-193.7 \mathrm{~nm}$ の $1.5 \mathrm{ng}$, 錠剤-197.3 nm の 2.2 $\mathrm{ng}$, 溶液- $197.3 \mathrm{~nm}$ の $2.7 \mathrm{ng}$ の順であり，水素炎の場 合の約 10 倍の感度を示した. 検量線は溶液, 錠剂とも $193.7 \mathrm{~nm}$ で $0 \sim 0.15 \mu \mathrm{g}, 197.3 \mathrm{~nm}$ で $0 \sim 0.3 \mu \mathrm{g}$ あで 直線を示した. $0.1 \mu \mathrm{g}$ の標準溶液による 10 回繰り返し の相対標準偏差はいずれの組み合わせとも $(1.7 〜 2.3) \%$ であった. STHB を溶液として用いた場合に比べて錠 㶡の場合, $20 \%$ 程度感度の向上がみられた。一方, 加熱 石英セル法の場合, 酸素に増感効果のあることが知ら れ ${ }^{13) 14)}$ ，著者らの装置においても溶液法で $(15 \sim 20) \mathrm{ml}$ の酸素を系内に注入すれば $50 \%$ 程度感度が向上する. 従って，錠剂法での感度向上は錠剂投入時に系内に混入 する空気中の酸素によるものと考えられる．溶液法の感 度向上のために一定量の 酸素を注入することも試みた が, この場合, 溶液法では本来検出されないバックグラ ウンド吸収が現れ，従来必要としなかったバックグラウ ンド補正が必要となる. 又, 精度も低下する傾向がみら れた。ゆえに，今回は酸素による増感効果は採用しなか った. 試料の測定に当たっては検量線の直線域の広い $197.3 \mathrm{~nm}$ の共鳴線を用い, STHB は溶液と錠剤の両方 を使用した。

\section{2 共存元素の影響}

大気粉じん中には鉄，マンガン，亜鉛，銅などがヒ素

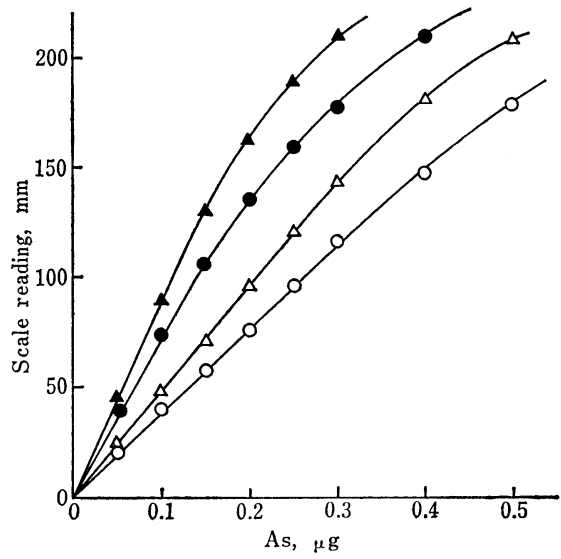

Fig. 3 Calibration curves for As STHB solution-197.3 nm; STHB solution-193.7
$\mathrm{nm} ; \triangle$ STHB tablet-197.3 nm; $\triangle$ STHB tablet-193.7 nm
の数千倍〜数万倍含まれる.このような系への本法の適 用性を調べるため，七素 (V) $0.1 \mu \mathrm{g}$ に対して (1000〜 50000) 倍の種々金属イオンを添加して吸光度を測定し た (Table 1).

Table 1 Effect of diverse ions

\begin{tabular}{|c|c|c|c|c|c|}
\hline \multirow{2}{*}{ Ion } & \multirow{2}{*}{ Added as } & \multirow{2}{*}{$\begin{array}{c}\text { Added } \\
(\mu \mathrm{g})\end{array}$} & \multicolumn{3}{|c|}{ As found $(\mu \mathrm{g})$} \\
\hline & & & $3 \%$ & STHB solution & STHB tablet \\
\hline $\mathrm{Al}^{3+}$ & $\mathrm{AlCl}_{3}$ & 5000 & & 0.101 & 0.098 \\
\hline $\mathrm{Ba}^{2+}$ & $\mathrm{BaCl}_{2}$ & 5000 & & 0.100 & 0.097 \\
\hline $\mathrm{Ca}^{2+}$ & $\mathrm{CaCl}_{2}$ & 5000 & & 0.101 & 0.100 \\
\hline $\mathrm{Cd}^{2+}$ & $\mathrm{CdCl}_{2}$ & 5000 & & 0.101 & 0.098 \\
\hline \multirow{3}{*}{$\mathrm{Co}^{2+}$} & $\mathrm{CoCl}_{2}$ & 5000 & & 0.058 & 0.045 \\
\hline & & 2500 & & 0.089 & 0.065 \\
\hline & & 1000 & & 0.098 & 0.097 \\
\hline $\mathrm{Cr}^{3+}$ & $\mathrm{CrCl}_{3}$ & 5000 & & 0.098 & 0.097 \\
\hline $\mathrm{Cu}^{2+}$ & $\mathrm{CuCl}_{2}$ & 5000 & & 0.098 & 0.097 \\
\hline $\mathrm{Fe}^{3+}$ & $\mathrm{FeCl}_{3}$ & 5000 & & 0.098 & 0.099 \\
\hline \multirow[t]{2}{*}{$\mathrm{Hg}^{2+}$} & $\mathrm{HgCl}_{2}$ & 5000 & & 0.095 & 0.078 \\
\hline & & 2500 & & 0.098 & 0.098 \\
\hline $\mathrm{K}^{+}$ & $\mathrm{KCl}$ & 5000 & & 0.100 & 0.101 \\
\hline $\mathrm{Li}^{+}$ & $\mathrm{LiCl}$ & 5000 & & 0.102 & 0.101 \\
\hline $\mathrm{Mg}^{2+}$ & $\mathrm{MgCl}_{2}$ & 5000 & & 0.100 & 0.098 \\
\hline $\mathrm{Mn}^{2+}$ & $\mathrm{MnCl}_{2}$ & 5000 & & 0.098 & 0.097 \\
\hline $\mathrm{Mo}^{6+}$ & $\left(\mathrm{NH}_{4}\right)_{6} \mathrm{Mo}_{7} \mathrm{O}_{24}$ & 5000 & & 0.100 & 0.099 \\
\hline $\mathrm{Na}^{+}$ & $\mathrm{NaCl}$ & 5000 & & 0.102 & 0.100 \\
\hline \multirow[t]{3}{*}{$\mathrm{Ni}^{2+}$} & $\mathrm{NiCI}_{2}$ & 5000 & & 0.056 & 0.016 \\
\hline & & 250 & & 0.089 & 0.067 \\
\hline & & 100 & & 0.099 & 0.098 \\
\hline $\mathrm{Pb}^{2+}$ & $\mathrm{Pb}\left(\mathrm{NO}_{3}\right)_{2}$ & 5000 & & 0.099 & 0.098 \\
\hline $\mathrm{Sr}^{3+}$ & $\mathrm{Sr}\left(\mathrm{NO}_{3}\right)_{3}$ & 5000 & & 0.098 & 0.097 \\
\hline $\mathrm{V}^{5+}$ & $\mathrm{NH}_{4} \mathrm{VO}_{3}$ & 5000 & & 0.097 & 0.101 \\
\hline \multirow[t]{2}{*}{$\mathrm{Zn}^{2+}$} & $\mathrm{Zn}\left(\mathrm{NO}_{3}\right)_{2}$ & 5000 & & 0.097 & 0.085 \\
\hline & & 2500 & & 0.098 & 0.097 \\
\hline
\end{tabular}

As taken : $0.100 \mu \mathrm{g}$

ニッケル(II) 以外の元素は数万倍共存しても全く影 響を与えなかった，大気粉じん中のニッケルは通常七素 の 10 倍以下であり, ニッケルによる干渉は今回の目的 に対しては無視できる．STHB を溶液とする場合と錠 剂とした場合とでは，溶液のほうがやや共存イオンによ る干渉を受けにくい傾向が認められた。 Lーアスコルビン 酸はヨウ素による配管の污染を防止するために加えたも ので, $20 \%$ 溶液 $5 \mathrm{ml}$ を加えても七素の定量には全く影 響しない.

\section{3 大気粉じんの分解抽出法の検討}

ヒ素を分析する場合の試料の分解抽出法としては, ア ルカリ溶融, 硫酸一硝酸, 硫酸一硝酸ーフッ化水素酸などに よる方法がよく用いられている15). 一方，大気粉じん 中の重金属の分析に扎いては，硝酸一過酸化水素水，硝 酸一塩酸, 塩酸-過酸化水素水による方法が用いられてい $る^{16)}$. 環境科学では多成分の分析が必要であり，共通の 
分解法が適用できることが望ましい，今回，ビル屋上の 外気取入ロフィルターから採取した大気粉じんを用いて これらの分解抽出法を検討した（Table 2).

Table 2 Comparison of wet digestion methods for ambient particulates

\begin{tabular}{cccc}
\hline Digestion method & $\begin{array}{c}\text { A.F.D. taken } \\
(\mathrm{g})\end{array}$ & $\begin{array}{c}\text { As added } \\
(\mu \mathrm{g})\end{array}$ & $\begin{array}{c}\text { As found } \\
(\mu \mathrm{g})\end{array}$ \\
\hline $\mathrm{HF}-\mathrm{HNO}_{3}-\mathrm{H}_{2} \mathrm{SO}_{4}$ & 0 & 0.50 & 0.48 \\
& 0.50 & 0 & 16.1 \\
& 0.50 & 15.0 & 32.0 \\
$\mathrm{HNO}_{3}-\mathrm{H}_{2} \mathrm{SO}_{4}$ & 0 & 0.50 & 0.49 \\
& 0.50 & 0 & 16.5 \\
$\mathrm{HNO}_{3}-\mathrm{H}_{2} \mathrm{O}_{2}$ & 0.50 & 15.0 & 31.8 \\
& 0 & 0.50 & 0.48 \\
& 0.50 & 0 & 16.8 \\
$\mathrm{H}_{2} \mathrm{SO}_{4}-\mathrm{H}_{2} \mathrm{O}_{2}$ & 0.50 & 15.0 & 31.3 \\
& 0 & 0.50 & 0.52 \\
& 0.50 & 0 & 16.3 \\
$\mathrm{HCl}-\mathrm{HNO}_{3}$ & 0.50 & 15.0 & 32.0 \\
& 0 & 0.50 & 0.38 \\
& 0.50 & 0 & 15.3 \\
$\mathrm{HCl}-\mathrm{H}_{2} \mathrm{O}_{2}$ & 0.50 & 15.0 & 28.9 \\
& 0 & 0.50 & 0.25 \\
& 0.50 & 0 & 14.5 \\
& 0.50 & 15.0 & 25.4 \\
\hline
\end{tabular}

A.F.D. : Air filter dust

硫酸-硝酸-フッ化水素酸, 硫酸-硝酸, 硝酸一過酸化水 素水あるいは硝酸による方法は, 標準溶液, 粉じんから の抽出液, 一定量の七素を添加した粉じんからの抽出液 のいずれもがそれぞれ $5 \%$ 以内の誤差で一致した值を 示した. しかし，硝酸一塩酸及び塩酸一過酸化水素水によ る方法は，前者の方法と比べ低い值となった．これはヒ 素が塩化物として揮散したためと考えられる. 以上の結 果から，七素分析に当たっては大気粉じん中の鉄，マン ガン，銅，亜鉛などを分析する場合の標準的前処理法と されている硝酸-過酸化水素水による方法を用いること とした.

\section{4 大気粉じんの分析結果}

ハイボリウム・エア・サンプラーを用いてヒ素含量の 少ない石英織維ろ紙 (Gelman No.66100) ${ }^{17}$ ) 上に捕集 した大気粉じんの分析結果を Table 3 に示した.

抽出液に一定量の七素を添加した場合の添加量と回収 量の関係は STHB を溶液として用いた場合も，錠剤と して用いた場合も $\pm 10 \%$ 以内の誤差でよく一致した。

$$
4 \text { 絬望芒 }
$$

ヨウ化カリウムと STHB を用いるアルシン発生一加 熱石英セル原子吸光法が，大気粉じん中の $(0.05 \sim 0.3)$ $\mu \mathrm{g}$ の七素の高感度定量法として適用できること, 又大 気粉じん中のヒ素は硝酸一過酸化水素水で加熱すること によって定量的に抽出できることが分かった．なお，本 法に拈いて, 七素の数万倍の鉄 (III), 亜鉛 (II), 銅(II)
Table 3 Analytical results of As in ambient particulates

\begin{tabular}{|c|c|c|c|c|c|}
\hline \multirow{3}{*}{$\begin{array}{c}\text { Sample } \\
\text { R-1 }\end{array}$} & \multirow{3}{*}{$\begin{array}{c}\text { As added }(\mu \mathrm{g}) \\
\begin{array}{l}0 \\
0.050 \\
0.100\end{array}\end{array}$} & \multicolumn{4}{|c|}{ As found $(\mu \mathrm{g})$} \\
\hline & & \multicolumn{2}{|c|}{ Solution } & \multicolumn{2}{|c|}{ Tablet } \\
\hline & & $\begin{array}{l}0.078 \\
0.130 \\
0.175\end{array}$ & $(54.2)$ & $\begin{array}{l}0.080 \\
0.125 \\
0.174\end{array}$ & $(55.6)$ \\
\hline $\mathrm{R}-2$ & $\begin{array}{l}0 \\
0.050 \\
0.100\end{array}$ & $\begin{array}{l}0.070 \\
0.122 \\
0.167\end{array}$ & $(31.5)$ & $\begin{array}{l}0.073 \\
0.120 \\
0.169\end{array}$ & (32.8) \\
\hline $\mathrm{U}-1$ & $\begin{array}{l}0 \\
0.050 \\
0.100\end{array}$ & $\begin{array}{l}0.075 \\
0.127 \\
0.172\end{array}$ & $(70.2)$ & $\begin{array}{l}0.072 \\
0.120 \\
0.172\end{array}$ & (67.3) \\
\hline$P-1$ & $\begin{array}{l}0 \\
0.050 \\
0.100\end{array}$ & $\begin{array}{l}0.085 \\
0.140 \\
0.185\end{array}$ & $(79.2)$ & $\begin{array}{l}0.085 \\
0.128 \\
0.177\end{array}$ & $(79.0)$ \\
\hline$P-2$ & $\begin{array}{l}0 \\
0.050 \\
0.100\end{array}$ & $\begin{array}{l}0.095 \\
0.142 \\
0.192\end{array}$ & (109) & $\begin{array}{l}0.089 \\
0.141 \\
0.189\end{array}$ & (102) \\
\hline I -1 & $\begin{array}{l}0 \\
0.050 \\
0.100\end{array}$ & $\begin{array}{l}0.110 \\
0.162 \\
0.220\end{array}$ & (106) & $\begin{array}{l}0.108 \\
0.162 \\
0.199\end{array}$ & (104) \\
\hline I -2 & $\begin{array}{l}0 \\
0.050 \\
0.100\end{array}$ & $\begin{array}{l}0.076 \\
0.130 \\
0.172\end{array}$ & $(80.2)$ & $\begin{array}{l}0.080 \\
0.121 \\
0.175\end{array}$ & $(84.4)$ \\
\hline
\end{tabular}

$\mathrm{R}$ : Rural area; $\mathrm{U}$ : Urban area; $\mathrm{P}$ : Petroleum industrial area; I : Iron and steel industrial area; ( ) As content in ambient particulates, ppm

などは全く妨害しない．加熱石英セル原子化法を用いる ことにより水素炎法の約 10 倍の感度が得られた.

\section{文献}

1) D. J. von Lehmdem, R. H. Jungers, R. E. Lee : Anal. Chem., 46, 239 (1974).

2) 山本勇麓, 熊丸尚宏, 林 康久, 鎌田俊彦 : 分 化，22，876 (1973).

3) 鎌田俊彦，奥田久徳，熊丸尚宏，山本勇麓：衛生 化学, 19, 314 (1973).

4) Y. Yamamoto, T. Kumamaru, Y. Hayashi, T. Kamada : Bull. Chem. Soc. Jpn., 46, 2604 (1973).

5) J. C. Van Loon, E. J. Brooker : Anal. Lett., 7, 505 (1974).

6) Y. Yamamoto, T. Kumamaru : Fresenius' $Z$. Anal. Chem., 281, 353 (1976).

7) 中島 進: 分化, 28, 561 (1979).

8) Y. Yamamoto, T. Kumamaru : Fresenius' $Z$. Anal. Chem., 282, 139 (1976).

9) 山本勇麓, 熊丸尚宏, 江戸哲夫, 竹本淳司 : 分 化， 25，770 (1976).

10）山重 隆, 大本幸達, 重富康正 : 分化, 27, 607 (1978).

11) 山重 隆，重富康正：日化，1978，972.

12) J. R. Knechtel, J. L. Fraser : Analyst (London), 103, 104 (1978).

13) P. D. Goulden, P. Brooksbank : Anal. Chem., 46, 1431 (1974).

14) D. D. Siemer : Anal. Lett., 8, 323 (1975).

15) 平野四蔵：“無機応用比色分析”，1 巻， p. 135 (1973)，（共立出版).

16) 環境庁大気保全局：大気污染物質測定法指針， (I), p. 4 (1979), (環境庁).

17) 山重 隆, 大本幸達：公害と対策, 16, 751(1980). 


\begin{abstract}
A sensitive method for determination of arsenic in ambient particulates utilizing arsine generation followed by heated quartz cell atomic absorption spectrophotometry. Takashi YAMASHIGE*, Manabu Yамамото and Yuroku Yамамото** (*Hiroshima Prefectural Research Center for Environmental Science, 1-6-29, Minami-machi, Minami-ku, Hiroshima-shi, Hiroshima; **Department of Chemistry, Faculty of Science, Hiroshima University, 1-1-89, Higashisenda-machi, Naka-ku, Hiroshima-shi, Hiroshima)

A quite sensitive method for determination of arsenic in ambient particulates was described which utilized arsine generation with a sodium borohydride reduction followed by heated quartz cell atomic absorption spectrophotometry. Several wet digestion methods were also examined for the extraction of arsenic from ambient particulates, and it was concluded that digestion with $\mathrm{HNO}_{3} / \mathrm{H}_{2} \mathrm{O}_{2}$ was the most satisfactory. The procedure is as follows. A given amount of particulates sample was gently heated in concentrated nitric acid together with a small amount of hydrogen peroxide
\end{abstract}

on a hot plate. After filtering an insoluble residue off, the filtrate was evaporated to dryness and dissolved in $50 \mathrm{ml}$ of $0.5 \mathrm{~mol} / \mathrm{l}$ hydrochloric acid. Then take $20 \mathrm{ml}$ of the solution containing less than $0.3 \mu \mathrm{g}$ of arsenic, $3 \mathrm{ml}$ of concentrated hydrochloric acid, $1 \mathrm{ml}$ of $40 \%$ potassium iodide solution and $1 \mathrm{ml}$ of $20 \%$ $\mathrm{L}$-ascorbic acid solution into a reaction vessel. After displacing air by nitrogen, $2.5 \mathrm{ml}$ of $3 \%$ sodium borohydride solution, or one sodium borohydride tablet was added into the reaction vessel. After $30 \mathrm{~s}$, generated arsine was swept into the heated quartz cell with nitrogen gas. By the present method, $(0.05 \sim$ $0.3) \mu g$ of arsenic in ambient particulates was determined satisfactorily within an error of $5 \%$.

(Received Nov. 13, 1980)

\section{Keyword phrases}

determination of arsenic in ambient particulates; heated quartz cell atomic absorption spectrophotometry; sodium borohydride solution and tablet.

\title{
非イオン性界面活性剤水溶液系におけるテノイル トリフルオロアセトンとトリオクチルホスフィン オキシドを用いるウランの吸光光度定量法
}

\author{
竹田津 富次*®，合 原 真，木元 裕子**
}

(1981 年 1 月 12 日受理)

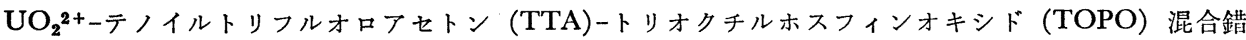
体は非イオン性界面活性剤（ノナオキシェチレンドデシルェーテル）水溶液に可溶化され， $376 \mathrm{~nm} に$ 極大吸収を持つ吸収スペクトルを与える. この水溶液は $\mathrm{pH} 3.4 \sim 4.8$ で一定の吸光度を示し, $\mathrm{UO}_{2}{ }^{2+}$ として 0〜16 $\mu \mathrm{g} \mathrm{ml}^{-1}$ の濃度範囲でべールの法則が成立する. モル吸光係数は $2.1 \times 10^{4} \mathrm{~cm}^{-1} \mathrm{~mol}^{-1}$ $\mathrm{dm}^{3}$ である. EDTA をマスキング郕として用いることにより，トリウム，ジルコニウム，鉄など多く のイオンの妨害を除去できる.
\end{abstract}

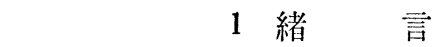

先にユウロピウム, サマリウムの TTA-TOPO 混合 錯体及び鉄(III) の TTA 錯体を非イオン性界面活性剂 により可溶化した水溶液系を用いて，それぞれ，けい光

*九州大学教養部 : 福岡県福岡市中央区六本松 4-2-1

** 福岡女子大学家政学部 : 福岡県福岡市東区香住ケ丘 $1-1$
光度法1)，分光光度法"2)によりこれらの金属イオンを定 量する方法を報告した．これらの方法では，溶媒抽出法 3)4)に比べて，TTA の使用量が少量で済むため，前者 では紫外部領域に拉ける励起光に対する吸収が小さく強 いけい光強度が得られ，後者では紫外部の吸収極大の測 定が可能になることから，いずれも定量感度を大幅に増 大させることができた。

本報では $\mathrm{UO}_{2}{ }^{2+}-\mathrm{TTA}$-TOPO 混合錯体を非イオン 